\title{
Integrated torrefaction vs. external torrefaction - A thermodynamic analysis for the case of a thermochemical biorefinery
}

\section{Clausen, Lasse Røngaard}

\section{Published in:}

Energy

Link to article, DOI:

10.1016/j.energy.2014.09.042

Publication date:

2014

Document Version

Peer reviewed version

Link back to DTU Orbit

\section{Citation (APA):}

Clausen, L. R. (2014). Integrated torrefaction vs. external torrefaction - A thermodynamic analysis for the case of a thermochemical biorefinery. Energy, 77, 597-607. https://doi.org/10.1016/j.energy.2014.09.042

\section{General rights}

Copyright and moral rights for the publications made accessible in the public portal are retained by the authors and/or other copyright owners and it is a condition of accessing publications that users recognise and abide by the legal requirements associated with these rights.

- Users may download and print one copy of any publication from the public portal for the purpose of private study or research.

- You may not further distribute the material or use it for any profit-making activity or commercial gain

- You may freely distribute the URL identifying the publication in the public portal 


\title{
Integrated torrefaction vs. external torrefaction - a thermodynamic analysis for the case of a thermochemical biorefinery
}

\author{
Lasse R. Clausen* \\ Section of Thermal Energy, Department of Mechanical Engineering, The Technical University of Denmark (DTU), \\ Nils Koppels Allé Bld. 403, DK-2800 Kgs. Lyngby, Denmark
}

Received: $x \mathbf{x}$

\begin{abstract}
Integrated and external torrefaction is analyzed and compared via thermodynamic modeling. In this paper, integrated torrefaction is defined as torrefaction integrated with entrained flow gasification. External torrefaction is defined as the decentralized production of torrefied wood pellets and centralized conversion of the pellets by entrained flow gasification. First, the syngas production of the two methods was compared. Second, the two methods were compared by considering complete biorefineries with either integrated torrefaction or external torrefaction. The first part of the analysis showed that the biomass to syngas efficiency can be increased from $63 \%$ to $86 \%$ (LHV-dry) when switching from external torrefaction to integrated torrefaction. The second part of the analysis showed that the total energy efficiency (biomass to methanol + net electricity) could be increased from $53 \%$ to $63 \%$ when switching from external torrefaction to integrated torrefaction. The costs of this increase in energy efficiency are as follows: 1) more difficult transport, storage and handling of the biomass feedstock (wood chips vs. torrefied wood pellets); 2) reduced plant size; 3) no net electricity production; and 4) a more complex plant design.
\end{abstract}

Keywords: biorefinery, biofuel, torrefaction, gasification, syngas, thermodynamic analysis.

\section{Introduction}

Torrefaction is a low temperature pyrolysis process that can be used as a pretreatment process for biomass. The process can also be referred to as a roasting process and is, e.g., used for roasting coffee beans in the production of coffee. The torrefaction of woody biomass operates typically at $250-300^{\circ} \mathrm{C}$ and produces a solid fuel with properties that resemble those of coal. These properties include increased energy density, improved grindability/pulverization, hydrophobic nature, etc. Torrefaction is typically envisioned to be done decentralized, followed by pelletization or briquetting to lower handling, transportation and storage cost. The pretreated biomass can then be sent to a central biomass processing facility [1-3].

Because torrefied biomass has similar properties as coal, it can be gasified using commercial entrained flow coal gasifiers $[4,5]$. This can enable a relatively quick shift from coal to biomass for syngas production. In [5], torrefied wood powder is gasified in a $270 \mathrm{kWth}$ oxygen-blown pressurized entrained flow gasifier. The gas produced consist of $\mathrm{H}_{2}, \mathrm{CO}, \mathrm{CO}_{2}, \mathrm{H}_{2} \mathrm{O}$ and $0,9-1,8$ mole\% $\mathrm{CH}_{4}$, together with small amounts of higher hydrocarbons, including tar and soot. A low content of hydrocarbons $\left(\sim \mathrm{CH}_{4}\right)$, and a high content of $\mathrm{H}_{2}$ and $\mathrm{CO}$, is preferable when using the syngas for chemical synthesis. It is concluded in [5] that torrefaction reduces the $\mathrm{CH}_{4}$ content in the syngas, and it is shown that increasing the torrefaction temperature from $300^{\circ} \mathrm{C}$ to $340^{\circ} \mathrm{C}$ lowers the $\mathrm{CH} 4$ content, but at the cost of a lower cold gas efficiency [5]. The disadvantage of entrained flow gasification of torrefied biomass is the relatively low cold gas efficiency achieved due to the high temperature in the gasifier. When also considering the

*Corresponding author. Tel.: +45 20712778; fax: +45 45884325. E-mail address: Irc@mek.dtu.dk (L.R. Clausen). 
loss of heating value in the torrefaction step the "overall cold gas efficiency" becomes even lower. A method to increase the cold gas efficiency of entrained flow gasification of torrefied biomass has been presented by Mark Prins et al. [4]. The method is about integrating the torrefaction step with the entrained flow gasification. This means that the torrefaction process is done centralized at the gasifier and not decentralized, resulting in higher transportation, handling and storage cost of the untreated biomass compared to torrefied biomass pellets [6].

This paper will compare centralized torrefaction with the more conventional decentralized torrefaction, or when the perspective of a centralized plant is taken; compare external torrefaction to integrated torrefaction. This paper will add to the knowledge that is available in the open literature about integrated torrefaction, by building on top of the analysis performed by Prins et. al. in [4]. This paper will examine the integration between torrefaction and gasification more closely - mainly concerning the increase in the overall cold gas efficiency. Some of the questions answered include: what causes the increase in the overall cold gas efficiency? How do torrefaction conditions influence the increase in overall cold gas efficiency? How does the overall cold gas efficiency compare with external torrefaction or no torrefaction? These questions are answered by thermodynamic modelling of the biomass to syngas conversion (torrefaction + gasification). The integrated torrefaction process will however benefit from heat integration with the downstream syngas conversion processes; such as the conversion of syngas to fuel product, or syngas to electricity. Because of this, the paper will also show the impact of using either external torrefaction or integrated torrefaction in a thermo-chemical biorefinery via thermodynamic modeling and analysis. The impact is assessed by comparing the fuel energy efficiencies as well as the total energy efficiencies along with an assessment of the complexity of the plant designs. Many studies have been published on modelling and analysis of thermo-chemical biorefineries, such as [7-11], but none have used integrated torrefaction.

\section{Integrating torrefaction with entrained flow gasification}

The concept of integrated torrefaction is presented in Fig. 1. It shows how the volatile gasses produced in the torrefaction process can be converted to syngas when using entrained flow gasification [4].

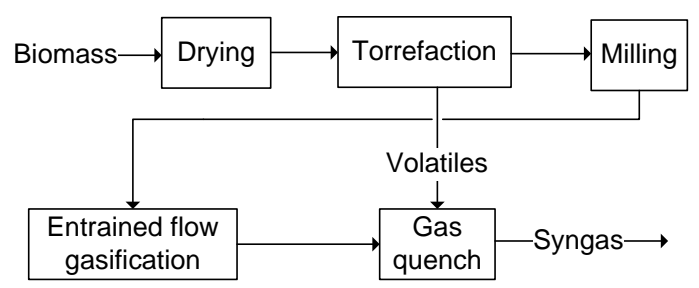

Fig. 1. Simplified flow sheet showing the idea behind integrated torrefaction as presented in [4]. Note: for case $c$ and $d$ presented in the text: biomass $=$ wood chips (willow)

In decentralized torrefaction, the volatile gasses are typically combusted to produce heat for drying and torrefaction [2]. In a centralized plant, the use of medium and low temperature waste heat for drying and torrefaction is more optimal, and the volatile gases can then be used to chemically quench the high temperature gas from the gasifier and thereby increase the production of syngas ${ }^{1}$. The method was proposed by Mark Prins et al. in [4]. Mark Prins et al. write that "due to the high temperature, the thermally unstable volatiles from the torrefaction step will decompose into carbon monoxide and hydrogen" [4]. This claim is the core of the integrated torrefaction process and is therefore also a prerequisite for this paper. It should be noted that the claim still needs to be verified by experiments. If

\footnotetext{
${ }^{1}$ When pressurized entrained flow gasification is used, the volatiles must be pressurized before the gas quench (Fig. 1). This pressurization can either be done by 1) pressurizing the volatiles after torrefaction, 2) pressurized torrefaction, 3) a combination of options 1 and 2 .
} 
future experiments show that the volatiles are not decomposed into hydrogen and carbon monoxide to a very significant extent, the method would probably not be attractive, especially if significant amounts of tar compounds in the volatiles from torrefaction "survive" the high temperature quench. If this shows to be the case, a dedicated downstream tar reforming/cleaning process, similar to what is used when gasification is done in fluidized beds, would be required. A dedicated downstream tar reforming/cleaning process would normally not be needed after an entrained flow gasifier $[5,12]^{2}$. To evaluate the integrated torrefaction process, a parameter called the "overall cold gas efficiency" is defined as follows:

overall cold gas efficiency $=\frac{\dot{m}_{\text {syngas }} \cdot L H V_{\text {syngas }}}{\dot{m}_{\text {biomass }, \text { dry }} \cdot L H V_{\text {biomass }, \text { dry }}}$

This parameter is the total energy efficiency for the integrated system, which consists of torrefaction and gasification (and gas quench).

In section 2.2, the values for the overall cold gas efficiency are presented for four cases. The cases are a) without torrefaction (Fig. 2), b) external torrefaction (Fig. 3), c) integrated torrefaction at $250^{\circ} \mathrm{C}$ (Fig. 1) and d) integrated torrefaction at $300^{\circ} \mathrm{C}$ (Fig. 1). The modeling approach used to generate the results for the four cases is presented in section 2.1.

${ }^{2}$ This is true for coal gasification [5,13], and experiments performed in $[5,12]$ with wood and torrefied wood indicate the same. 


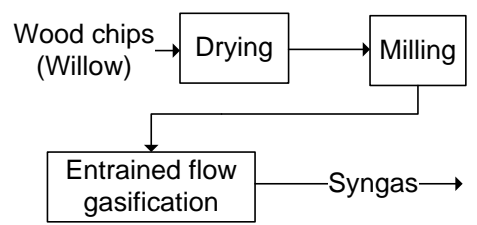

Fig. 2. Simplified flow sheet of syngas production from willow without torrefaction. Note: Untreated willow is assumed to be able to be gasified in an entrained flow gasifier. Moreover, the same gasification conditions as those used for torrefied wood are assumed applicable.

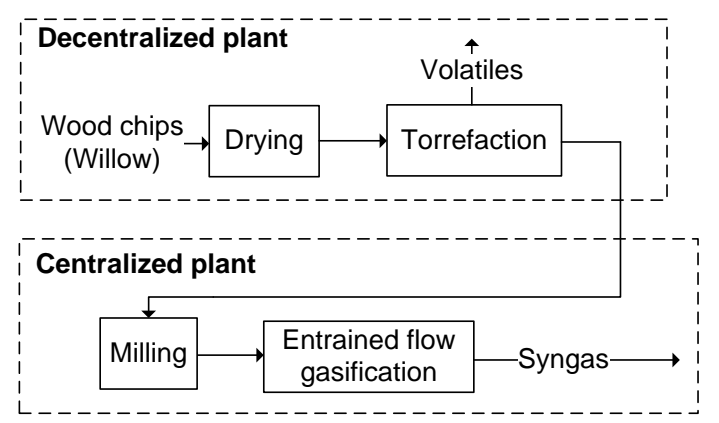

Fig. 3. Simplified flow sheet of syngas production from willow with external/decentralized torrefaction. Note: The torrefied product would be densified by pelletization or briquetting before transportation. This process is not considered in this simplified approach.

\subsection{Modeling of torrefaction and gasification}

Torrefaction is modeled in a certain way for the case of external torrefaction and in another way for the cases of integrated torrefaction. For external torrefaction, simply using the energy efficiency of torrefaction is adequate (eq. (2)), but for integrated torrefaction, torrefaction is modeled in more detail based on two torrefaction experiments presented in [4].

energy efficiency of torrefaction $=\frac{\dot{m}_{\text {torr_wood }} \cdot L H V_{\text {torr_wood }}}{\dot{m}_{\text {biomass,dry }} \cdot L H V_{\text {biomass,dry }}}$

The two experiments are summarized in Fig. 4. The two experiments estimate the reaction heat for torrefaction to be lower than $1 \%$ of the LHV of the wood input, but the estimation is associated with an uncertainty of $2.2 \%-2.5 \%$ of the LHV of the wood input. The two experiments also show that only $1 \%$ of the heating value in the wood input is lost in the torrefaction process (converted to sensible heat). 

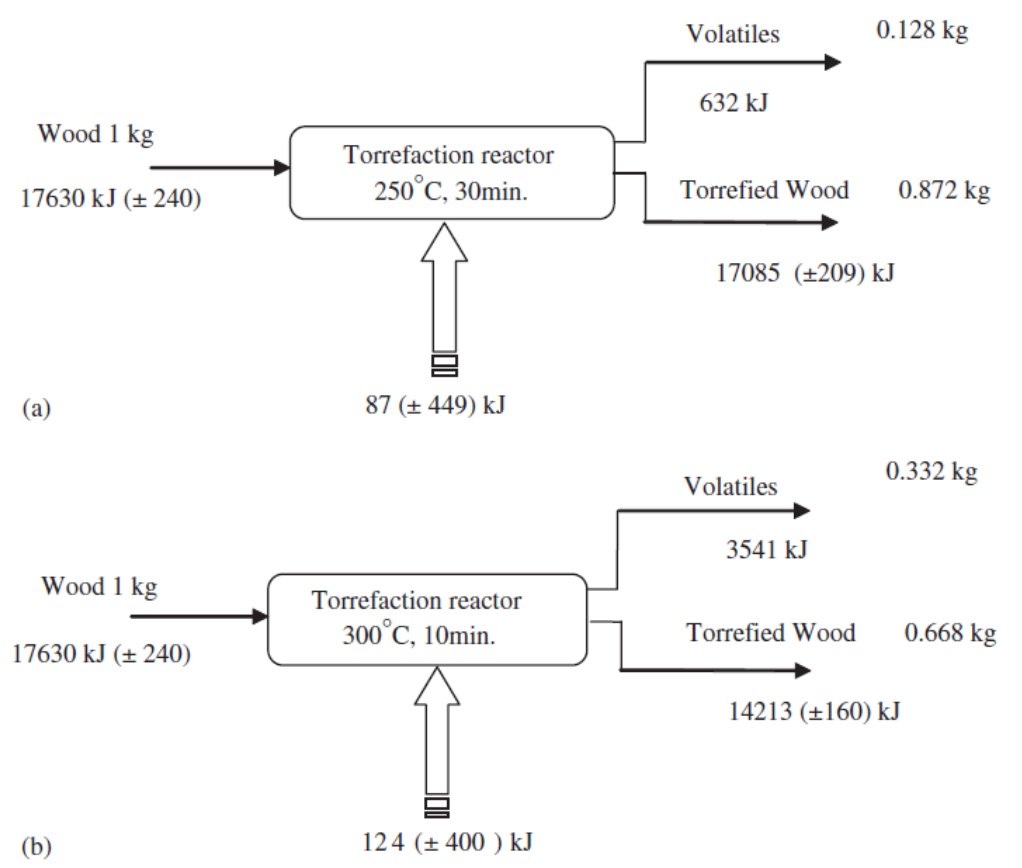

Fig. 4. Overall mass and energy balances for torrefaction of dry willow at temperature and reaction time of (a) $250^{\circ} \mathrm{C}$ and 30 $\min \left(\right.$ b) $300^{\circ} \mathrm{C}$ and $10 \mathrm{~min}$. Figure from [4]. The energy content given for volatiles and torrefied wood is a sum of chemical energy and sensible heat. Note: In [4], the content of chemical energy and sensible heat is also stated separately.

For external torrefaction, the energy efficiency of torrefaction is set to $80 \%$ (dry LHV) irrespective of the torrefaction temperature. This setting agrees with a review on torrefaction [1] and with data on the production of torrefied wood pellets $[14,15]^{3}$. An energy efficiency of torrefaction of $80 \%$ also matches the torrefaction efficiency from [4] at $300^{\circ} \mathrm{C}$, and [14] shows that the energy content of the volatiles is sufficient to meet the heat demand for drying and torrefaction when torrefaction proceeds at $300^{\circ} \mathrm{C}$. It should however be noted that the energy efficiency of torrefaction at a lower temperature (e.g., $250^{\circ} \mathrm{C}$ ) can be higher than $80 \%$ if the energy demand for drying (and torrefaction) is met by using external waste heat instead of burning some of the biomass.

\footnotetext{
${ }^{3}$ The torrefaction energy efficiency is close to $80 \%$ for external torrefaction irrespective of the torrefaction temperature because of the heat requirement for drying. The heat requirement for drying is independent of the torrefaction temperature and much higher than the heat requirement for torrefaction. In many references, torrefaction efficiencies higher than $80 \%$ are stated, e.g. $[14,15]$. The efficiencies in these references are based on LHV on wet basis instead of dry basis. This difference can clearly be seen in table 2.2 in [15] and figures 4.4 and 4.5 in [14]. One of the consequences of basing the energy efficiency on LHV wet basis is that the process of drying wood will produce heating value, even though chemical reactions do not take place.
} 
Table 1

Dry composition (in wt\%) of solid fuels used in the analysis.

\begin{tabular}{|c|c|c|c|c|}
\hline & $\begin{array}{r}\text { Wood chips } \\
\text { (willow) }\end{array}$ & $\begin{array}{l}\text { Torrefied wood } \\
\left(250^{\circ} \mathrm{C}, 30 \mathrm{~min}\right) \\
\end{array}$ & $\begin{array}{l}\text { Torrefied wood } \\
\left(300^{\circ} \mathrm{C}, 10 \mathrm{~min}\right)\end{array}$ & $\begin{array}{r}\text { Torrefied wood } \\
\text { pellets } \\
\end{array}$ \\
\hline Carbon & 47.2 & 51.3 & 55.8 & 50.8 \\
\hline Hydrogen & 6.1 & 5.9 & 5.6 & 5.8 \\
\hline Oxygen & 45.1 & 40.9 & 36.2 & 41.4 \\
\hline Nitrogen & 0.3 & 0.4 & 0.5 & 0.3 \\
\hline Sulfur & $0.02^{b}$ & $0.02^{c}$ & $0.03^{c}$ & 0.06 \\
\hline Ash & 1.3 & 1.5 & 1.9 & 1.7 \\
\hline LHV (dry basis) [MJ/kg] & 17.6 & 19.4 & 21.0 & 20.6 \\
\hline $\begin{array}{l}\text { Moisture content } \\
{[\mathrm{wt} \%]}\end{array}$ & $5.0^{d}$ & 0 & 0 & 3.0 \\
\hline $\mathrm{c}_{\mathrm{p}}[\mathrm{kJ} /(\mathrm{kg} \cdot \mathrm{K})]$ & $1.35^{\mathrm{e}}$ & $1.28^{f}$ & $1.18^{f}$ & $1.35^{\mathrm{e}}$ \\
\hline Reference & [4] & [4] & {$[4]$} & {$[2,16]$} \\
\hline
\end{tabular}

${ }^{a}$ The torrefied wood pellets are assumed to be the fuel produced in the case of "external torrefaction", ${ }^{\mathrm{b}}$ sulfur content from [jespers paper], ${ }^{c}$ calculated based on ${ }^{b},{ }^{d}$ assumed value after drying (before torrefaction), ${ }^{e}$ assumed value, ${ }^{f}$ calculated based on e. $^{\circ}$

The entrained flow gasification process is modeled by assuming chemical equilibrium at the exit of the gasifier. Due to the high temperature of $1300^{\circ} \mathrm{C}$ at the exit of the gasifier, this assumption is good $[4,13,17]^{4}$. The process parameters set for the gasification process are shown in Table 3 under "gasifier". The chemical quench that occurs when the hot gas from the gasifier is mixed with the volatiles from torrefaction is modeled by assuming that the volatiles are completely converted to $\mathrm{H}_{2}, \mathrm{CO}, \mathrm{H}_{2} \mathrm{O}$ and $\mathrm{CO}_{2}$, as suggested by [4], and that these four gas components are at chemical equilibrium at the exit temperature and pressure of the quench. These assumptions are most accurate at high temperature, which corresponds to a low mass flow of volatiles (low torrefaction temperature). Gas compositions before and after the chemical quench can be seen in Table 4 (integrated torrefaction), and in Table 5 the gas composition of the gas from the gasifier in the case of external torrefaction can be seen.

\subsection{Results and discussion}

The results show that the highest overall cold gas efficiency is $86 \%$ for integrated torrefaction at a torrefaction temperature of $300^{\circ} \mathrm{C}$. The lowest overall cold gas efficiency is $63 \%$ for external torrefaction (Fig. 5). This difference is mainly due to the utilization of the volatiles from torrefaction. In integrated torrefaction, the volatiles are converted to syngas, whereas the volatiles are combusted and the heat used for drying and torrefaction in external torrefaction. Because the volatiles contain $19 \%$ of the heating value of the input wood when torrefaction is performed at $300^{\circ} \mathrm{C}$, the impact of combusting the volatiles instead of producing syngas is significant.

\footnotetext{
${ }^{4}$ The methane content may be higher than predicted by chemical equilibrium as indicated in [5]. The experiments in [5] are done on a small gasifier ( $270 \mathrm{kWth})$. It is expected that increasing the gasifier size to commercial scale, which could be 1000 times bigger ( $270 \mathrm{MWth}$ ), would lower the methane content. When using coal instead of biomass, the methane content is lower than predicted by chemical equilibrium [13].
} 


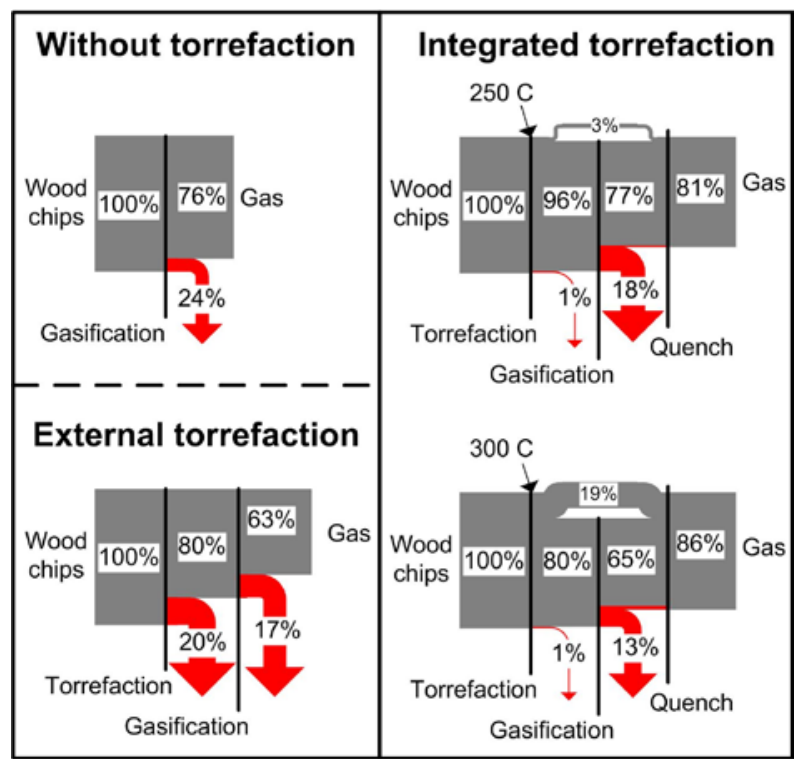

Fig. 5. Sankey diagram of the chemical energy flows and conversion heat losses for the four different cases. The chemical energy flows are based on LHV (dry basis).

The case without torrefaction achieves an overall cold gas efficiency of $76 \%$. Therefore, integrating torrefaction can increase the overall cold gas efficiency by up to $10 \%$-points (to $86 \%$ ). The $10 \%$-point increase can be split into four categories, as shown in Table 2. The most important categories for integrated torrefaction at $300^{\circ} \mathrm{C}$ are "volatiles avoiding gasifier" (4.6\%-points) and "increase in cold gas efficiency of gasifier" (4.2\%-points). For integrated torrefaction at $250^{\circ} \mathrm{C}$, the "increase in cold gas efficiency of gasifier" (3.9\%-points) accounts for almost all of the increase in overall cold gas efficiency (increase of 4.5\%-points). The chemical quench that occurs when the volatiles are mixed with the hot gas from the gasifier also provides an important contribution to the overall cold gas efficiency for the case of integrated torrefaction at $300^{\circ} \mathrm{C}(2.2 \%$-points), whereas the contribution for the case of integrated torrefaction at $250^{\circ} \mathrm{C}$ is much lower (0.5\%-points). This difference is expected, as the volatiles contain almost six times more energy when torrefaction occurs at $300^{\circ} \mathrm{C}$ compared to $250^{\circ} \mathrm{C} \mathrm{(Fig.} \mathrm{5).} \mathrm{The}$ results achieved for the cases of integrated torrefaction match well with the data from $[4]^{5}$.

\footnotetext{
${ }^{5}$ From table 3 in [4], an exergy efficiency from wood to product gas can be calculated to be 15178/20023=75.8\% for case IIla and $16050 / 20023=80.2 \%$ for case IIIb (entrained flow gasification at $1200^{\circ} \mathrm{C}$ integrated with torrefaction at $250^{\circ} \mathrm{C}(\mathrm{IIla})$ or $300^{\circ} \mathrm{C}$ (IIIb)). Figure 6 in [4] shows that the physical exergy content of the gas is negligible because it is calculated after the gas cooler/HRSG. If a wood to gas chemical exergy efficiency is calculated for the present cases, the results are $73.6 \%$ and $78.5 \%$ for torrefaction at $250^{\circ} \mathrm{C}$ and $300^{\circ} \mathrm{C}$, respectively. If the model is changed so that entrained flow gasification is performed at $1200^{\circ} \mathrm{C}$ instead of $1300^{\circ} \mathrm{C}$, the results become $75.0 \%$ and $79.5 \%$ for torrefaction at $250^{\circ} \mathrm{C}$ and $300^{\circ} \mathrm{C}$, respectively.
} 
Table 2

The effect on the overall cold gas efficiency of adding torrefaction.

\begin{tabular}{|c|c|c|c|c|}
\hline & $\begin{array}{l}\text { Without } \\
\text { torrefaction }\end{array}$ & $\begin{array}{r}\text { External } \\
\text { torrefaction }\end{array}$ & $\begin{array}{r}\text { Integrated } \\
\text { torrefaction, } \\
250^{\circ} \mathrm{C}\end{array}$ & $\begin{array}{r}\text { Integrated } \\
\text { torrefaction, } \\
300^{\circ} \mathrm{C}\end{array}$ \\
\hline Cold gas efficiency of gasifier [\%] & 76.1 & 79.7 & 80.2 & 81.4 \\
\hline Overall cold gas efficiency [\%] & 76.1 & 63.4 & 80.7 & 86.3 \\
\hline $\begin{array}{l}\text { Increase in overall cold gas efficiency compared } \\
\text { with "without torrefaction" [\%-points] }\end{array}$ & - & -12.8 & 4.5 & 10.2 \\
\hline \multicolumn{5}{|l|}{$\begin{array}{l}\text { The total increase given in the row above is split } \\
\text { into increments in the following rows [\%-points]: }\end{array}$} \\
\hline 1. Increase in cold gas efficiency of gasifier & - & 2.8 & 3.9 & 4.2 \\
\hline 1.1 Decrease in moisture content of fuel ${ }^{a}$ & - & 0.6 & 1.6 & 1.4 \\
\hline 1.2 Temperature change of fuela,b & - & -0.4 & 1.1 & 1.2 \\
\hline $\begin{array}{l}1.3 \text { Change in fuel composition (LHV, } c_{p} \text {, } \\
\text { ultimate analysis) }^{\text {a }}\end{array}$ & - & 2.6 & 1.2 & 1.7 \\
\hline 2. Volatiles avoiding gasifier & - & - & 0.8 & 4.6 \\
\hline 3. Chemical quench & - & - & 0.5 & 2.2 \\
\hline 4. Loss of LHV in torrefaction & - & -15.6 & -0.7 & -0.9 \\
\hline
\end{tabular}

a The splitting between 1.1-1.3 is done by doing parameter variation in the thermodynamic model ${ }^{\mathrm{b}} \mathrm{A}$ temperature of $115^{\circ} \mathrm{C}$ is assumed in "without torrefaction", $60^{\circ} \mathrm{C}$ in "external torrefaction", $250^{\circ} \mathrm{C}$ or $300^{\circ} \mathrm{C}$ in integrated torrefaction.

\section{Design of the biorefineries}

The analysis presented in the previous section of the paper for the cases of integrated torrefaction assumed that the heat demand for drying and torrefaction was met by available waste heat in the downstream processing. This part of the paper investigates the correctness of this assumption by considering the case of a thermochemical biorefinery. The two cases, external torrefaction and integrated torrefaction at $300^{\circ} \mathrm{C}$, are therefore expanded to show the effect on plant design and energy efficiencies of using either external or integrated torrefaction in a biorefinery.

The simplified flow sheets of the two investigated biorefineries are shown in Fig. 6 and Fig. 7. The biorefineries are modeled in Aspen Plus and an in-house modeling tool called DNA [18] ${ }^{6}$. The design process parameters used in the modeling are presented in Table 3. Important parts of the plant design are presented below together with the modeling approach ${ }^{7}$. The biorefinery based on external torrefaction is to a great extent based on a biorefinery producing dimethyl ether (DME) presented in [10].

\footnotetext{
${ }^{6}$ The gasification part is modelled in DNA and the rest of the biorefinery in Aspen Plus. The property methods used in Aspen Plus are: PR-BM (Peng-Robinson with Boston-Mathias alpha function) for the syngas processing, SR-POLAR (Schwarzentruber and Renon) for the methanol reactor loop and the distillation, and STEAMNBS for the integrated steam plant.

${ }^{7}$ The modeling approach for the torrefaction part is described in section 2.1 above. It is only the torrefaction part that is directly based on experimental data, the rest of the plants consists of conventional components that can be modelled by using the process design parameters given in Table 3.
} 


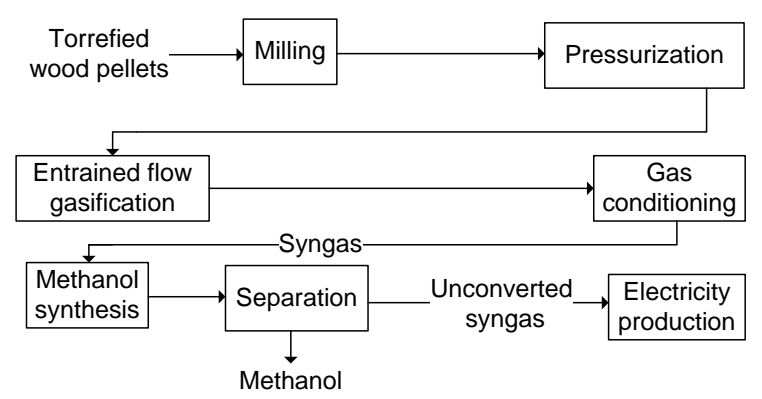

Fig. 6. Simplified flow sheet of the methanol plant based on torrefied wood pellets (external torrefaction)

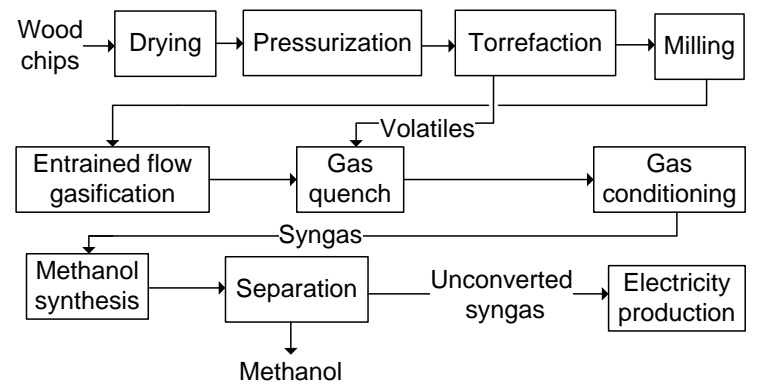

Fig. 7. Simplified flow sheet of the methanol plant based on wood chips (integrated torrefaction)

\subsection{Size of the biorefineries}

The size of the biorefinery based on torrefied wood pellets is set to $2312 \mathrm{MWth}$ input as in [10]. The size of the biorefinery based on wood chips is reduced to $500 \mathrm{MWth}$ input because wood chips are more bulky and have a lower energy density than torrefied wood pellets. Therefore, they are more expensive to transport over very long distances. For comparison, some kraft pulp and paper mills are bigger than $500 \mathrm{MWth}$ [19]. Because this study does not include an economic analysis, the exact sizes of the plants do not impact the results and conclusions of the paper.

\subsection{Pretreatment \& feeding}

The torrefied wood is assumed to be pretreated and fed with existing commercial coal technology $[2,3]$. The torrefied wood pellets are milled to powder, and the powder is pressurized with lock hoppers and fed to the gasifier with pneumatic feeders, both of which use $\mathrm{CO}_{2}$ from the carbon capture process downstream. The wood chips are fist dried in a steam dryer, then pressurized with lock hoppers, torrefied at $300^{\circ} \mathrm{C}$ and milled to powder, which is fed to the gasifier with pneumatic feeders ${ }^{8}$.

\subsection{Gasification}

A commercial, dry-fed, slagging ${ }^{9}$ entrained flow coal gasifier is used to gasify the torrefied wood powder. The gasifier is oxygen blown and pressurized to 45 bar [20]. A cryogenic air separation unit provides the oxygen supply. A gas quench using $200^{\circ} \mathrm{C}$ recycled syngas downstream of the dry solids removal lowers the temperature of the syngas from $1300^{\circ} \mathrm{C}$ to $900^{\circ} \mathrm{C}$ for the biorefinery using external torrefaction. For the biorefinery using integrated torrefaction, the temperature is lowered by quenching the syngas at $1300^{\circ} \mathrm{C}$ with the volatiles from the torrefaction process upstream. The composition of the

\footnotetext{
${ }^{8}$ Could also be torrefied at lower pressure and then pressurized further after milling, but this approach would also mean that the volatiles from torrefaction would need to be pressurized at high temperature to the gasification pressure.

${ }^{9}$ Because of the low ash content in biomass, a slag recycle is needed to ensure that the gasifier slags [16]. Moreover, see note $c$ below Table 3.
} 
syngas after the gasifier and after the chemical quench with the volatiles is calculated by assuming chemical equilibrium at the exit temperature and pressure (compositions given in Table 4 and Table 5).

\subsection{Gas cooling and water gas shift}

The syngas is further cooled to $200^{\circ} \mathrm{C}$ by generating superheated steam ${ }^{10}$. A sulfur tolerant ${ }^{11}$ water gas shift (WGS) reactor adjusts the $\mathrm{H}_{2} / \mathrm{CO}$ ratio to two to optimize methanol synthesis according to Eq. 3 . After the WGS reactor, the gas is cooled prior to the acid gas removal step.

\subsection{Gas cleaning}

The gas cleaning of biomass syngas for methanol synthesis includes cyclones and filters for particle removal placed just after the high temperature syngas cooler, an acid gas removal (AGR) step and guard beds ${ }^{12}$ placed just before the synthesis reactor $[23,24]$. The AGR step is performed with a chilled methanol process similar to the Rectisol process [10], and it removes sulfur components $\left(\mathrm{H}_{2} \mathrm{~S}\right.$ and $\left.\operatorname{COS}^{13}\right), \mathrm{CO}_{2}$ and other species, such as $\mathrm{NH}_{3}$ and $\mathrm{HCl} . \mathrm{CO}_{2}$ is vented to the atmosphere and the sulfur components are sent to the gas turbine. The $\mathrm{H}_{2} \mathrm{~S}+\mathrm{COS}$ content in the syngas after AGR is approximately $0.1 \mathrm{ppm}[25]$, and the $\mathrm{CO}_{2}$ content is $1.2-1.5$ mole $\%{ }^{14}$.

The energy input for the AGR process is primarily electricity to power a cooling plant, but electricity is also used to run pumps that pressurize the methanol solvent. A heat input is used to cover the reboiler duty of the water removal column and the sulfur removal column.

\subsection{Synthesis of methanol}

The syngas is compressed to 85 bar prior to entering the synthesis reactor. The reactor is modeled as an isothermal boiling water reactor that operates at $260^{\circ} \mathrm{C}$, where the methanol reaction (eq. 3 ) and the water gas shift reaction are assumed to reach an approach to equilibrium of $15^{\circ} \mathrm{C}$ [26]. The reactor product gas is cooled to $40^{\circ} \mathrm{C}$ to condense $98-99 \%$ of the produced methanol. A gas-liquid separator separates the liquid from the unconverted syngas, $97 \%$ (external torrefaction) or $88 \%$ (integrated torrefaction) of the unconverted syngas is recycled to the synthesis reactor. The remaining gas is sent to the gas turbine.

$2 \mathrm{H}_{2}+\mathrm{CO} \leftrightarrow \mathrm{CH}_{3} \mathrm{OH}$

\subsection{Distillation}

The liquid stream from the gas-liquid separator is distilled by fractional distillation in two columns. The first column is a topping column that separates the absorbed gasses from the liquid. The gas from the topping column, which consists mainly of $\mathrm{CO}_{2}$, is compressed and recycled back to the AGR. The second column separates water from methanol. The methanol liquid product achieves a purity of 99.9 mole\%. The feed to the distillation columns is preheated (partly evaporated) in most cases. This preheating lowers the reboiler duty and enables the utilization of lower temperature waste heat.

\footnotetext{
${ }^{10}$ Steam is superheated to $600^{\circ} \mathrm{C}$ in the gas cooling. Reference [20] states that only a "mild superheat" can be used in the gas cooling, but in [21] steam at 125 bar is superheated to $566^{\circ} \mathrm{C}$.

${ }^{11}$ E.g. Haldor Topsoe produces such catalysts [22]

$12 \mathrm{ZnO}$ and active carbon filters

${ }^{13}$ Sulfur is only modeled as $\mathrm{H}_{2} \mathrm{~S}$.

${ }_{14}$ The $\mathrm{CO}_{2}$ concentration before the methanol reactor is set to 3 mole\% to ensure catalyst activity in the methanol reactor [13].

The remaining $\mathrm{CO}_{2}$ will be supplied by the recycled unconverted syngas.
} 


\subsection{Heat integration and electricity production}

The heat integration within the biorefinery based on integrated torrefaction is more comprehensive and complex compared to the biorefinery based on external torrefaction. This complexity is due to the heat demand for drying and torrefaction. Therefore, the waste heat available for the integrated steam cycle is significantly reduced. The electricity production from the integrated steam cycle is supplemented by a gas turbine that operates on unconverted syngas. In the biorefinery based on integrated torrefaction, the gas turbine produces almost the same amount of electricity as the steam cycle to meet the on-site electricity consumption. In the biorefinery based on external torrefaction, the gas turbine produces 14 times less electricity than the steam cycle.

Table 3

Main process design parameters used in the modeling.

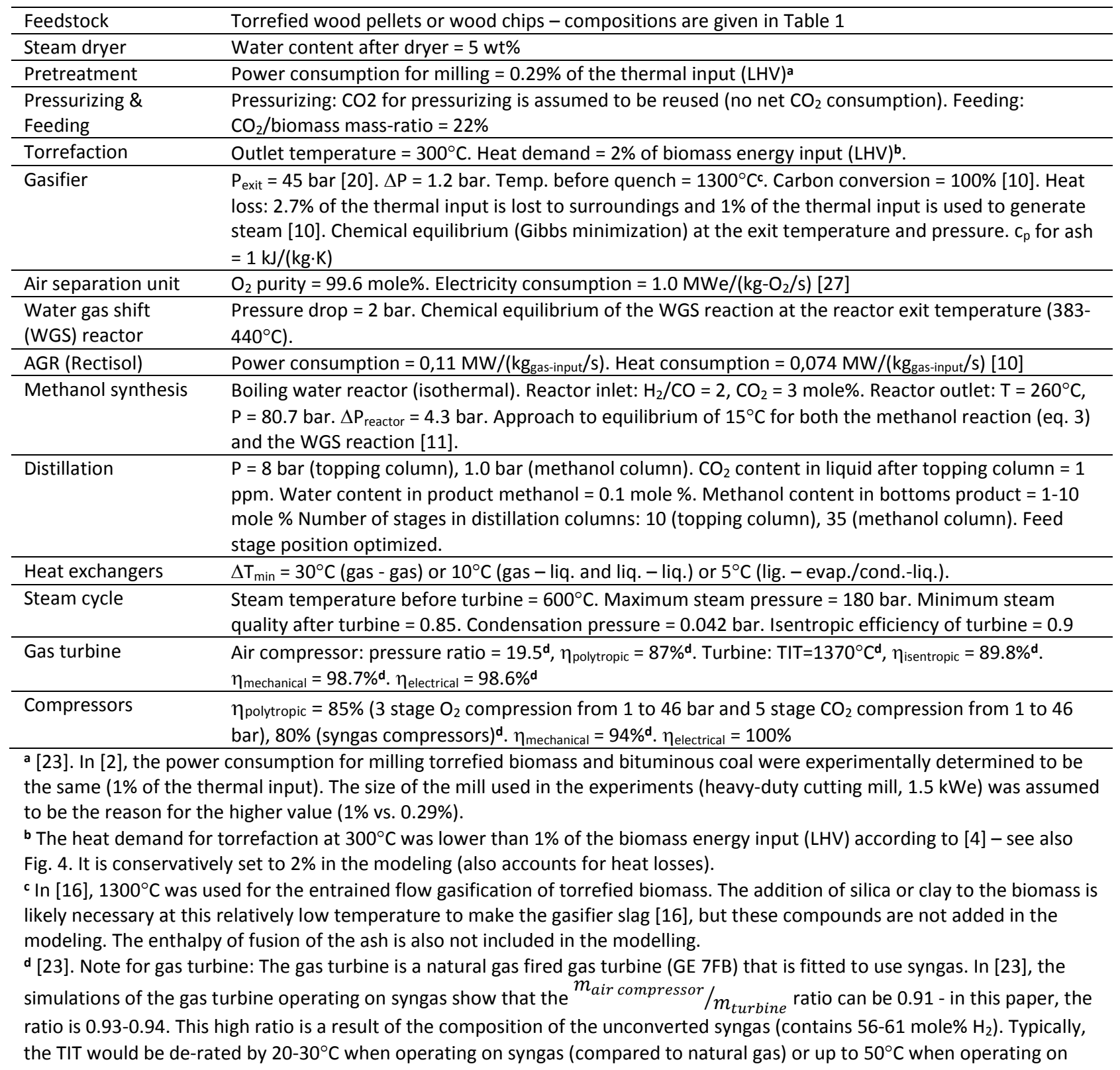


hydrogen. However, (as suggested in [23]), the historic increase in TIT is assumed to continue. Therefore, the TIT of $1370^{\circ} \mathrm{C}$ has not been de-rated.

\section{Results}

The results from the thermodynamic modeling of the two biorefineries are presented below. The flow sheets of the two plants are given in Fig. 8 and Fig. 9, accompanied by Table 4 and Table 5 with the compositions of selected mass flows. Table 6 compiles the main results. The results show higher energy efficiency in the biorefinery that uses integrated torrefaction compared to the biorefinery that uses external torrefaction. This difference was expected based on the results presented in section 2, which showed an increase in the biomass to syngas efficiency (overall cold gas efficiency) of $36 \%$ (from $63 \%$ to $86 \%)$ when converting from external torrefaction to integrated torrefaction. The calculated biomass to methanol + net electricity efficiencies is $53 \%$ for the biorefinery that uses external torrefaction, and $63 \%$ for the biorefinery that uses integrated torrefaction. This constitutes an increase of $20 \%$ when converting from external torrefaction to integrated torrefaction. This shows that the increase of $36 \%$ in energy efficiency for the syngas production (overall cold gas efficiency) is reduced to $20 \%$ when considering the total energy efficiency of the biorefineries. This reduction is mainly due to the heat requirement for drying and torrefaction, which lowers the on-site electricity production from the integrated steam cycle from $11 \%$ (external torrefaction) to $3 \%$ (integrated torrefaction) of the biomass / torrefied biomass energy input. Therefore, the net electricity production is $0 \%$ for the biorefinery based on integrated torrefaction, whereas it is $4 \%$ of the biomass energy input for the biorefinery based on external torrefaction. To cover the on-site electricity consumption in the biorefinery based on integrated torrefaction, the recycle ratio in the synthesis loop had to be reduced from $97 \%$ (external torrefaction) to $88 \%$ (integrated torrefaction) to increase the gas turbine electricity production. 


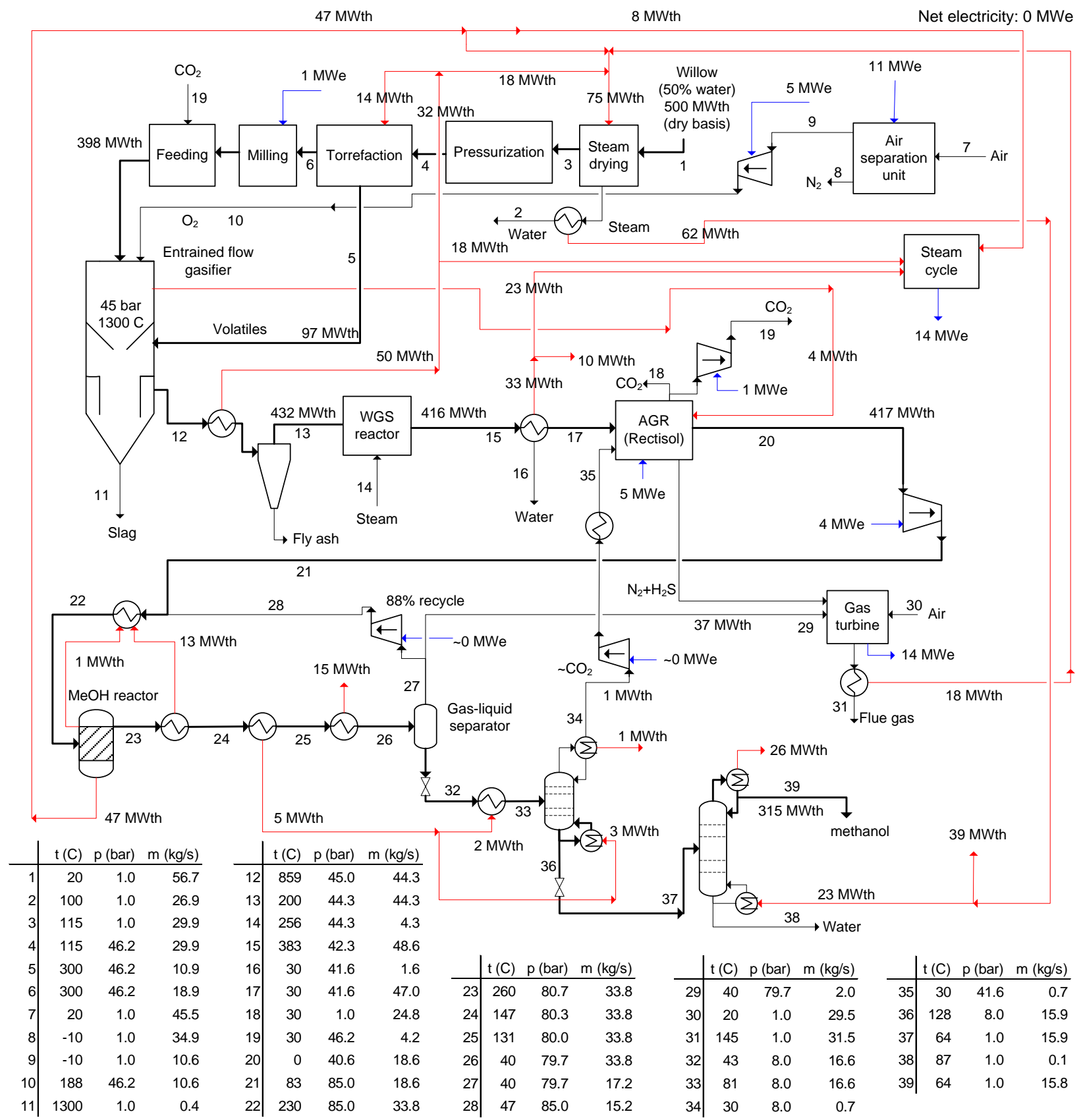

Fig. 8. Detailed flow sheet of the methanol plant based on wood chips (integrated torrefaction). The heat integration as well as power consumption and production are shown in the flow sheet. 
Table 4

Stream compositions for the methanol plant shown in Fig. 8 (integrated torrefaction).

\begin{tabular}{|c|c|c|c|c|c|c|c|c|c|}
\hline & $\begin{array}{l}\text { Gasifier } \\
\text { (before } \\
\text { quench) }\end{array}$ & $\begin{array}{r}\text { Gasifier } \\
\text { exit }\end{array}$ & $\begin{array}{r}\text { WGS } \\
\text { outlet }\end{array}$ & $\begin{array}{r}\text { AGR } \\
\text { outlet }\end{array}$ & $\begin{array}{r}\text { Reactor } \\
\text { inlet }\end{array}$ & $\begin{array}{r}\text { Reactor } \\
\text { outlet }\end{array}$ & $\begin{array}{r}\text { Purge } \\
\text { gas }\end{array}$ & $\begin{array}{l}\text { To distil- } \\
\text { lation }\end{array}$ & $\begin{array}{r}\text { Recycle } \\
\mathrm{CO}_{2}\end{array}$ \\
\hline $\begin{array}{l}\text { Stream } \\
\text { number }\end{array}$ & - & 12 & 15 & 20 & 22 & 23 & 29 & $32^{\mathrm{a}}$ & 34 \\
\hline $\begin{array}{l}\text { Mass flow } \\
(\mathrm{kg} / \mathrm{s})\end{array}$ & 33.4 & 44.3 & 48.6 & 18.6 & 33.8 & 33.8 & 2.0 & 16.6 & 0.7 \\
\hline $\begin{array}{l}\text { Mole flow } \\
\text { (kmole/s) }\end{array}$ & 1.50 & 2.15 & 2.39 & 1.66 & 2.81 & 1.82 & 0.15 & 0.51 & 0.02 \\
\hline \multicolumn{10}{|c|}{ Mole frac (\%) } \\
\hline $\mathrm{H}_{2}$ & 23.4 & 32.5 & 45.4 & 65.6 & 63.5 & 43.5 & 60.5 & 0.29 & 8.6 \\
\hline $\mathrm{CO}$ & 55.7 & 43.0 & 22.5 & 32.6 & 31.8 & 22.0 & 30.6 & 0.26 & 7.8 \\
\hline $\mathrm{CO}_{2}$ & 9.1 & 13.1 & 28.0 & 1.5 & 3.0 & 4.5 & 5.2 & 2.7 & 79.1 \\
\hline $\mathrm{H}_{2} \mathrm{O}$ & 11.2 & 11.2 & 3.9 & - & 0.00 & 0.17 & 0.00 & 0.59 & 0.00 \\
\hline $\mathrm{CH}_{4}$ & 0.02 & 0.02 & 0.02 & 0.03 & 0.11 & 0.17 & 0.24 & 0.01 & 0.32 \\
\hline $\mathrm{H}_{2} \mathrm{~S}$ & 0.01 & 0.01 & 0.01 & - & - & - & - & - & 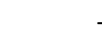 \\
\hline $\mathrm{N}_{2}$ & 0.20 & 0.14 & 0.13 & 0.19 & 0.92 & 1.4 & 2.0 & 0.02 & 0.51 \\
\hline $\mathrm{Ar}$ & 0.09 & 0.06 & 0.06 & 0.09 & 0.41 & 0.63 & 0.87 & 0.03 & 0.76 \\
\hline $\mathrm{CH}_{3} \mathrm{OH}$ & - & - & - & 0.03 & 0.29 & 27.6 & 0.67 & 96.1 & 2.9 \\
\hline
\end{tabular}

a Liquid

Table 5

Stream compositions for the methanol plant shown in Fig. 9 (external torrefaction).

\begin{tabular}{|c|c|c|c|c|c|c|c|c|}
\hline & $\begin{array}{r}\text { Gasifier } \\
\text { exit }\end{array}$ & $\begin{array}{l}\text { WGS } \\
\text { outlet }\end{array}$ & $\begin{array}{r}\text { AGR } \\
\text { outlet }\end{array}$ & $\begin{array}{r}\text { Reactor } \\
\text { inlet }\end{array}$ & $\begin{array}{r}\text { Reactor } \\
\text { outlet }\end{array}$ & $\begin{array}{r}\text { Purge } \\
\text { gas }\end{array}$ & $\begin{array}{r}\text { To distil- } \\
\text { lation }\end{array}$ & $\begin{array}{r}\text { Recycle } \\
\mathrm{CO}_{2}\end{array}$ \\
\hline Stream number & 7 & 11 & 16 & 18 & 19 & 26 & $29^{a}$ & 31 \\
\hline Mass flow $(\mathrm{kg} / \mathrm{s})$ & 187.2 & 221.4 & 77.2 & 173.6 & 173.6 & 3.0 & 74.2 & 2.9 \\
\hline $\begin{array}{l}\text { Mole flow } \\
\text { (kmole/s) }\end{array}$ & 8.76 & 10.66 & 6.95 & 13.64 & 9.21 & 0.21 & 2.31 & 0.08 \\
\hline \multicolumn{9}{|l|}{ Mole frac (\%) } \\
\hline $\mathrm{H}_{2}$ & 26.1 & 42.9 & 65.8 & 61.1 & 42.2 & 56.3 & 0.27 & 8.2 \\
\hline $\mathrm{CO}$ & 51.9 & 21.2 & 32.6 & 30.6 & 21.3 & 28.4 & 0.24 & 7.4 \\
\hline $\mathrm{CO}_{2}$ & 8.9 & 28.7 & 1.2 & 3.0 & 4.3 & 4.9 & 2.5 & 75.9 \\
\hline $\mathrm{H}_{2} \mathrm{O}$ & 12.9 & 7.0 & - & 0.00 & 0.16 & 0.00 & 0.64 & 0.00 \\
\hline $\mathrm{CH}_{4}$ & 0.03 & 0.02 & 0.05 & 0.56 & 0.84 & 1.1 & 0.05 & 1.5 \\
\hline $\mathrm{H}_{2} \mathrm{~S}$ & 0.02 & 0.02 & - & - & - & - & - & - \\
\hline $\mathrm{N}_{2}$ & 0.14 & 0.11 & 0.19 & 2.9 & 4.4 & 5.8 & 0.05 & 1.5 \\
\hline $\mathrm{Ar}$ & 0.07 & 0.06 & 0.11 & 1.5 & 2.2 & 2.9 & 0.09 & 2.6 \\
\hline $\mathrm{CH}_{3} \mathrm{OH}$ & - & - & 0.03 & 0.35 & 24.6 & 0.68 & 96.1 & 2.9 \\
\hline
\end{tabular}




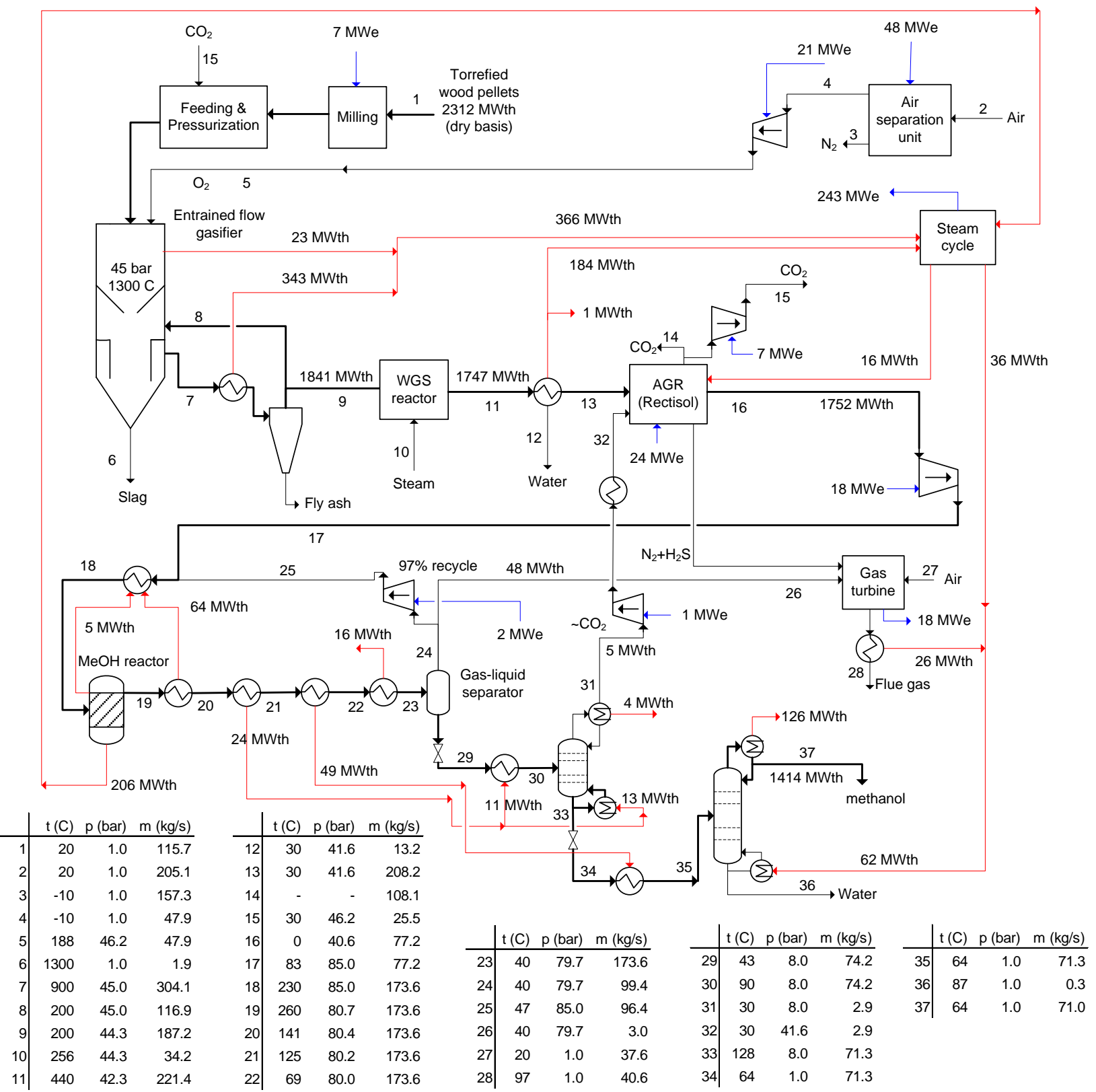

Fig. 9. Detailed flow sheet of the methanol plant based on torrefied wood pellets (external torrefaction). The heat integration as well as power consumption and production are shown in the flow sheet. 
Table 6

Main results from the modeling and analysis of the two biorefineries.

\begin{tabular}{|c|c|c|c|c|}
\hline & \multicolumn{2}{|c|}{ Integrated torrefaction } & \multicolumn{2}{|c|}{ External torrefaction } \\
\hline Biomass input [MWth] & \multirow{3}{*}{\multicolumn{2}{|c|}{$\begin{array}{r}500 \\
\text { [\% of biomass }\end{array}$}} & \multirow{2}{*}{\multicolumn{2}{|c|}{$\begin{array}{r}2906 \\
2312\end{array}$}} \\
\hline Torrefied biomass input [MWth] & & & & \\
\hline \multirow[b]{2}{*}{ Electricity consumption: } & & & & [\% of torrefied \\
\hline & [MWe] & input] & {$[\mathrm{MWe}]$} & biomass input] \\
\hline$\overline{\text { Air separation unit }}$ & 11 & 2 & 48 & 2 \\
\hline Milling & 1 & $\sim 0$ & 7 & $\sim 0$ \\
\hline Compressors & 11 & 2 & 49 & 2 \\
\hline Acid gas removal (AGR) & 5 & 1 & 24 & 1 \\
\hline Total electricity consumption & 28 & 6 & 127 & 5 \\
\hline \multicolumn{5}{|l|}{ Electricity production: } \\
\hline Steam cycle & 14 & 3 & 243 & 11 \\
\hline Gas turbine ${ }^{b}$ & 14 & 3 & 18 & 1 \\
\hline Total electricity production & 28 & 6 & 261 & 11 \\
\hline Net electricity production & 0 & 0 & 134 & 6 \\
\hline \multicolumn{5}{|l|}{ Energy efficiencies [\%]: } \\
\hline $\begin{array}{l}\text { Biomass to syngas } \\
\text { (Overall cold gas efficiency) }\end{array}$ & & 86 & & 63 \\
\hline Torrefied biomass to syngas & & - & & 80 \\
\hline Syngas to methanol & & 73 & & 77 \\
\hline Biomass to methanol & & 63 & & 49 \\
\hline Biomass to net electricity & & 0 & & 5 \\
\hline $\begin{array}{l}\text { Biomass to methanol + net electricity } \\
\text { (total efficiency) }\end{array}$ & & 63 & & 53 \\
\hline Torrefied biomass to methanol & & - & & 61 \\
\hline $\begin{array}{l}\text { Torrefied biomass to methanol + net } \\
\text { electricity }\end{array}$ & & - & & 67 \\
\hline
\end{tabular}

a the thermal efficiency of the steam cycles range from $36 \%$ for a simple cycle $\left(600^{\circ} \mathrm{C}\right.$ and 43 bar) to $42 \%$ for a cycle with reheat $\left(600^{\circ} \mathrm{C}\right.$ and $\left.180 \mathrm{bar}\right)$ - steam extraction is not included in these values. ${ }^{b}$ the thermal efficiency of the gas turbine is $37.9 \%$.

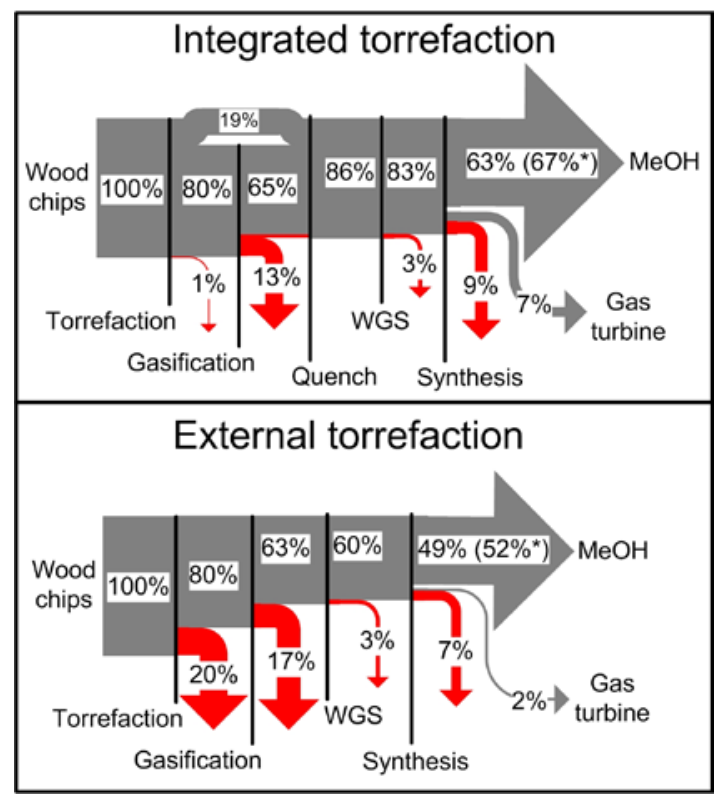

Fig. 10. Chemical energy flows (LHV-dry) and conversion heat losses (red) in the two biorefineries. Note: the torrefaction process occurs outside the plant for "external torrefaction". * The value given in parentheses is the energy value of methanol in the gas state (LHV). If this value is used, the width of the arrows before and after synthesis would be equal. 
Fig. 10 shows the chemical energy flows from wood chips to methanol for the two biorefineries. The figure clearly shows that the conversion heat losses for the syngas production part are much smaller for integrated torrefaction compared to external torrefaction, which was also shown in section 2 of this paper. The figure also shows that the unconverted syngas flow to the gas turbine is increased from $2 \%$ (external torrefaction) to 7\% (integrated torrefaction) of the biomass input. This increase aimed to meet the on-site electricity consumption.

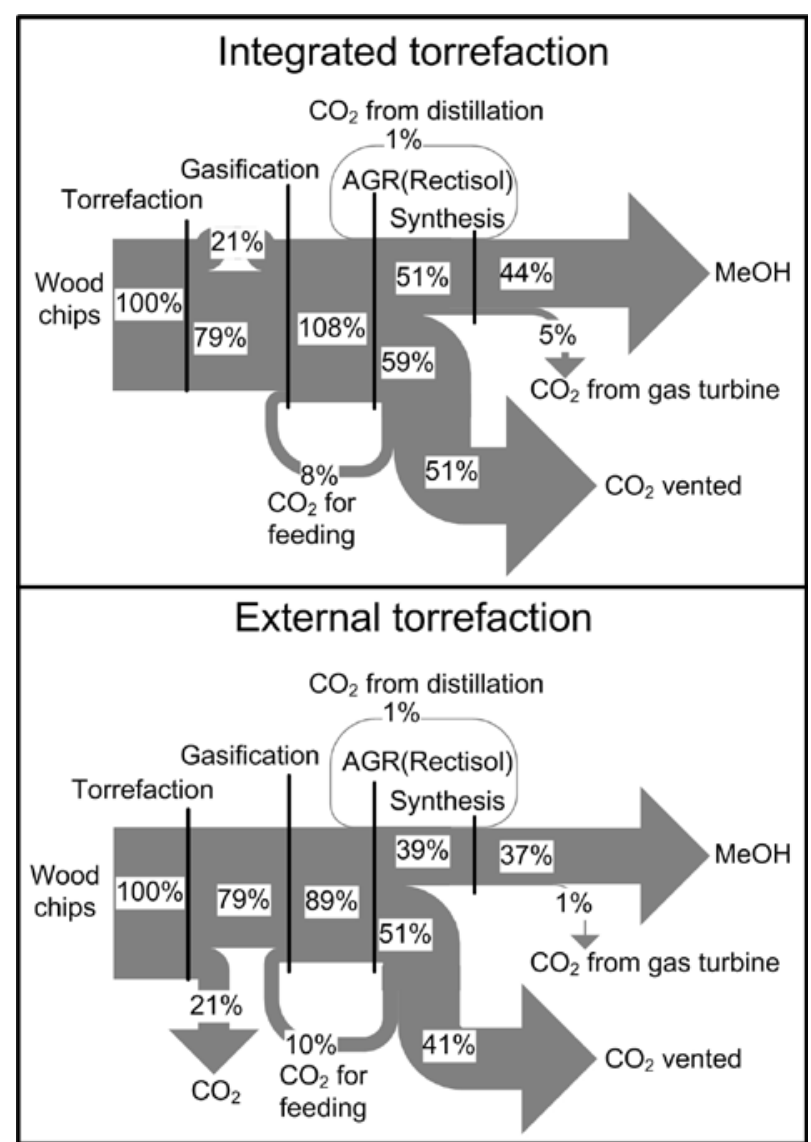

Fig. 11. Carbon flows in the two biorefineries.

Fig. 11 shows the carbon flows in the two biorefineries. The carbon flows to some extent resemble the energy flows from Fig. $10^{15}$. The majority of the carbon from the biomass is converted from $\mathrm{CO}$ to $\mathrm{CO}_{2}$ in the water gas shift (WGS) and then removed in the acid gas removal (AGR). Some of this $\mathrm{CO}_{2}$ is used to feed the biomass to the pressurized gasifier, and the rest is vented to the atmosphere. This pure $\mathrm{CO}_{2}$ stream could be pressurized and stored underground as done in [10]. This process would increase the on-site electricity consumption, which would result in lower methanol production for the biorefinery based on integrated torrefaction because more syngas would be needed for the gas turbine to meet the added electricity consumption.

\footnotetext{
${ }^{15}$ The loss of carbon in the torrefaction for the case of external torrefaction is an example: the loss of carbon matches the loss in chemical energy almost completely ( $21 \%$ vs. $20 \%)$.
} 


\section{Discussion}

The main results from the analysis of the two biorefineries can be summarized in the following: Switching from external torrefaction to integrated torrefaction will increase energy efficiency, but at the cost of a more complex plant design, reduced plant size, no net electricity production and more difficult transport, storage and handling of the biomass feedstock (Table 7). An economic analysis would be necessary to determine which of the two biorefineries would be able to produce methanol at the lowest cost.

Table 7

Pros and cons for the two investigated biorefineries

\begin{tabular}{|c|c|c|c|c|}
\hline & \multicolumn{2}{|c|}{ Pros } & \multicolumn{2}{|c|}{ Cons } \\
\hline $\begin{array}{l}\text { Integrated } \\
\text { torrefaction }\end{array}$ & 1. & Increased energy efficiency & & $\begin{array}{l}\text { More difficult transport, storage and handling } \\
\text { of the biomass feedstock (wood chips) } \\
\text { Smaller plant (economy of scale) } \\
\text { No net electricity production } \\
\text { More complex plant design }\end{array}$ \\
\hline $\begin{array}{l}\text { External } \\
\text { torrefaction }\end{array}$ & $\begin{array}{l}2 . \\
3 .\end{array}$ & $\begin{array}{l}\text { Easy transport, storage and handling of the } \\
\text { biomass feedstock (torrefied wood pellets) } \\
\text { Large plant (economy of scale) } \\
\text { Net electricity production }\end{array}$ & 1. & Reduced energy efficiency \\
\hline
\end{tabular}

a "More complex plant design" refers to: 1. the integrated torrefaction, e.g., pressurized torrefaction and/or pressurization of hot volatiles from torrefaction, 2. More complex heat integration in the plant (compare Fig. 8 with Fig. 9).

Two alternative designs for the biorefinery with integrated torrefaction are discussed below:

1) Increased methanol efficiency, 2) Atmospheric torrefaction and gasification.

1) Increased methanol efficiency: The methanol efficiency could be increased by increasing the recycle ratio in the synthesis loop from $88 \%$ to $97 \%$, which matches the recycle ratio used for external torrefaction. The syngas to methanol efficiency would thus be raised from $73 \%$ to $77 \%$, which also matches the syngas to methanol efficiency for external torrefaction (Table 6). This increase would increase the biomass to methanol efficiency from $63 \%$ to $66 \%$, but electricity would have to be imported to the plant as a consequence.

2) Atmospheric torrefaction and gasification: If atmospheric torrefaction and gasification are used as proposed in [4], the pressurization of solid wood prior to torrefaction and/or hot volatiles from torrefaction would be avoided. This approach would reduce the complexity of the integrated torrefaction. The most important consequence would be a 6 -fold increase in the electricity consumption of the syngas compressor (to $5 \%$ of the biomass energy input). If the electricity consumption is to be met on-site, the syngas consumption of the gas turbine would increase. This increase would reduce the total efficiency from $63 \%$ to $57 \%$. This efficiency is only slightly higher than the total efficiency of external torrefaction (53\%). Because electricity typically is valued higher than fuel, the difference in the total efficiency would be insignificant.

For external torrefaction, integrating waste heat from another source (e.g., industrial processing plant) in the production of torrefied wood pellets to dry the biomass would greatly increase the energy efficiency of torrefaction from $80 \%$ (wood to solid product efficiency for torrefaction at $300^{\circ} \mathrm{C}$ ) up to $96 \%$ (wood to solid product efficiency for torrefaction at $250^{\circ} \mathrm{C}$ ). 


\section{Conclusion}

Integrated and external torrefaction were analyzed and compared via thermodynamic modeling. The first part of the analysis showed that the biomass to syngas efficiency can be increased from $63 \%$ to $86 \%$ (LHV-dry) when switching from external torrefaction to integrated torrefaction at $300^{\circ} \mathrm{C}$. It also showed that integrated torrefaction at $250^{\circ} \mathrm{C}$ and gasification without torrefaction yield biomass to syngas efficiencies of $81 \%$ and $76 \%$, respectively. The increase in biomass to syngas efficiency when increasing the torrefaction temperature from $250^{\circ} \mathrm{C}$ to $300^{\circ} \mathrm{C}$ for integrated torrefaction was mainly due to 1) volatiles avoiding the gasifier and 2 ) the chemical quench that occurs when the volatiles are mixed with the hot gas from the gasifier. The increase in cold gas efficiency of the gasifier only contributed slightly to the increase in the overall biomass to syngas efficiency. The second part of the analysis showed that the total energy efficiency of a biorefinery could be increased from $53 \%$ to $63 \%$ (biomass to methanol + net electricity) when switching from external torrefaction to integrated torrefaction at $300^{\circ} \mathrm{C}$. This increase in energy efficiency incurs the following costs: 1) More difficult transport, storage and handling of the biomass feedstock (wood chips vs. torrefied wood pellets), 2) reduced plant size, 3) no net electricity production and 4) a more complex plant design. A detailed economic analysis is needed in order to decide which of the two biorefineries that would be most cost-effective. 


\section{References}

[1] van der Stelt MJC, Gerhauser H, Kiel JHA, Ptasinski KJ. Biomass upgrading by torrefaction for the production of biofuels: A review. Biomass Bioenergy 2011.

[2] Kiel JHA, Verhoeff F, Gerhauser H, Meuleman B. BO2-technology for biomass upgrading into solid fuel - pilotscale testing and market implementation. In: Proceedings for the 16th European Biomass Conference \& Exhibition. Valencia, Spain, 2008, p. 48-53. http://www.ecn.nl/publications/.

[3] Bergman PCA, Boersma AR, Kiel JHA, Prins MJ, Ptasinski KJ, Janssen FJJG. Torrefaction for entrained-flow gasification of biomass. Report: ECN-C--05-067. Petten, The Netherlands: ECN, 2005.

http://www.ecn.nl/publications/.

[4] Prins MJ, Ptasinski KJ, Janssen FJJG. More efficient biomass gasification via torrefaction. Energy 2006;31(15):3458-70.

[5] Weiland F, Nordwaeger M, Olofsson I, Wiinikka H, Nordin A. Entrained flow gasification of torrefied wood residues. Fuel Process Technol 2014;125:51-58.

[6] Uslu A, Faaij APC, Bergman PCA. Pre-treatment technologies, and their effect on international bioenergy supply chain logistics. Techno-economic evaluation of torrefaction, fast pyrolysis and pelletisation. Energy 2008;33(8):1206-23.

[7] Hamelinck CN, Faaij APC. Future prospects for production of methanol and hydrogen from biomass - System analysis of advanced conversion concepts by ASPEN-plus flowsheet modelling. Report: NWS-E-2001-49: Utrecht University (The Netherlands), Copernicus Institute, Department of Science, Technology and Society, 2001. http://www.mtholyoke.edu/courses/tmillett/course/geog 304B/e2001-49.pdf.

[8] Hamelinck C, Faaij A, den Uil H, Boerrigter H. Production of FT transportation fuels from biomass; technical options, process analysis and optimisation, and development potential. Energy 2004;29:1743-71.

[9] Larson ED, Jin H, Celik FE. Large-scale gasification-based coproduction of fuels and electricity from switchgrass. Biofuels, Bioproducts and Biorefining 2009;3(2):174-94.

[10] Clausen LR, Elmegaard B, Houbak N. Technoeconomic analysis of a low CO 2 emission dimethyl ether (DME) plant based on gasification of torrefied biomass. Energy 2010;35(12):4831-42.

[11] Clausen LR, Elmegaard B, Ahrenfeldt J, Henriksen U. Thermodynamic analysis of small-scale dimethyl ether (DME) and methanol plants based on the efficient two-stage gasifier. Energy 2011;36(10):5805-14.

[12] Weiland F, Hedman H, Marklund M, Wiinikka H, Öhrman O, Gebart R. Pressurized Oxygen Blown EntrainedFlow Gasification of Wood Powder. Energy Fuels 2013;27(2):932-941.

[13] Larson ED, Tingjin R. Synthetic fuel production by indirect coal liquefaction. Energy for Sustainable Development 2003;7(4):79-102.

[14] Bergman PCA. Torrefaction for biomass co-firing in existing coal-fired power stations. Report: ECN-C--05-013. Petten, The Netherlands: ECN, 2005. http://www.ecn.nl/publications/. 
[15] Bergman PCA. Combined torrefaction and pelletisation - The TOP process. Report: ECN-C--05-073. Petten, The Netherlands: ECN, 2005. http://www.ecn.nl/publications/.

[16] Van Der Drift A, Boerrigter H, Coda B, Cieplik MK, Hemmes K. Entrained-flow gasification of biomass; Ash behaviour, feeding issues, system analyses. Report: ECN-C--04-039. Petten, The Netherlands: ECN, 2004. http://www.ecn.nl/publications/.

[17] Qin K, Lin W, Jensen PA, Jensen AD. High-temperature entrained flow gasification of biomass. Fuel 2012;93:589-600.

[18] Elmegaard B, Houbak N. DNA - a general energy system simulation tool. In: SIMS 2005, 46th conference on simulation and modeling. Trondheim, Norway, 2005, p. 43-52.

http://www.scansims.org/sims2005/SIMS2005 16.pdf.

[19] Consonni S, Katofsky RE, Larson ED. A gasification-based biorefinery for the pulp and paper industry. Chem Eng Res Design 2009;87(9):1293-1317.

[20] van der Ploeg HJ, Chhoa T, Zuideveld PL. The Shell Coal Gasification Process for the US Industry. In: Proceedings for the Gasification Technology Conference. Washington DC, USA, 2004.

[21] The National Energy Technology Laboratory (NETL). Shell Gasifier IGCC Base Cases. Report: PED-IGCC-98-002, 1998 (revised in 2000). http://www.fischer-tropsch.org/DOE/DOE reports/PED-IGCC-98/PED-IGCC-98-

002/shell3x.pdf.

[22] Haldor Topsøe. Sulphur tolerant shift conversion. Web Page:

http://www.topsoe.com/Business areas/Gasification based/Processes/Sour shift.aspx (accessed April 25, 2014).

[23] Kreutz TG, Larson ED, Liu G, Williams RH. Fischer-Tropsch Fuels from Coal and Biomass. Report. Princeton, New Jersey: Princeton Environmental Institute, Princeton University, 2008.

http://www.princeton.edu/pei/energy/publications/texts/.

[24] van der Drift A, Boerrigter H. Synthesis gas from biomass. Report: ECN-C--06-001. Petten, The Netherlands: ECN, 2006. http://www.ecn.nl/publications/.

[25] Linde Engineering. Rectisol wash. Web Page: http://www.lindeengineering.com/en/process plants/hydrogen and synthesis gas plants/gas processing plants/rectisol wash/in dex.html (accessed April 25, 2014).

[26] Personal Communication with John Bøgild Hansen (Senior Scientist \& Adviser to Chairman, Company Mangement) and Poul Erik Højlund Nielsen (department manager of science \& innovation, R\&D), Haldor Topsøe A/S, 2010.

[27] Andersson K, Johnsson F. Process evaluation of an $865 \mathrm{MWe}$ lignite fired O2/CO2 power plant. Energy Conversion and Management 2006;47(18-19):3487-98. 